World Journal of Agricultural Sciences 7 (1): 78-85, 2011

ISSN 1817-3047

(C) IDOSI Publications, 2011

\title{
Impact of Secondary Metabolites and Related Enzymes in Flax Resistance and or Susceptibility to Powdery Mildew
}

\author{
${ }^{I}$ Naglaa A. Ashry and ${ }^{2}$ Heba I. Mohamed \\ ${ }^{1}$ Field Crops Research Inst., Agric. Res. Center, Giza, Egypt \\ ${ }^{2}$ Faculty of Education, Ain Shams University, Egypt
}

\begin{abstract}
Changes in various physiological defenses including secondary metabolites, proline, total soluble protein and antioxidant enzymes were investigated in leaves and stems of eighteen flax lines either resistant or susceptible to powdery mildew. The total alkaloids content in flax stems significantly increased in resistant lines meanwhile they decreased in susceptible ones and susceptible parent when the both compared with resistant parent. Stems of resistant flax lines contained a higher content of total phenols than susceptible ones upon pathogen challenge. The activity of peroxidase, polyphenyl oxidase, catalase enzymes as well as proline content were significantly increased in powdery mildew infected leaves of flax lines as compared with either resistant or susceptible parents. This increase was much pronounced in tolerant lines than resistant lines. Total soluble protein content in flax leaves increased in resistant lines and decreased in susceptible lines when comparing both with resistant parent.
\end{abstract}

Key words: Flax $\cdot$ Antioxidant enzymes $\cdot$ Phenol $\cdot$ Proline $\cdot$ Secondary metabolites

\section{INTRODUCTION}

Flax (Linum usitatissimum L.) is considered as the major bast fiber crop in Egypt and ranks just after cotton in relation to cultivated area and its economic importance [1]. Flax is cultivated in Egypt for both fiber and seed yields.

Powdery mildew (PM) is foliar disease attacks flax and is caused by Odium lini Skoric. The fungus attacks all aboveground parts of flax cultivars. In Egypt, it occurs wherever flax is cultivated when humidity and temperature conditions are favorable. Early infections may cause severe defoliation of flax plant and reduce yield and quality $[1,2]$. The symptoms are characterized by a white powdery mass of mycelia that starts as small spots and rapidly spreads to cover the entire leaf surface [3]. Currently this disease is considered the most common, conspicuous, widespread and easily recognized as foliar disease of flax in Egypt [4]. Over the last decade, the importance of this disease has increased probably due to the appearance and rapid distribution of new races capable to attack the present resistant cultivars [1].
Plants responds to pathogen attack or elicitor treatments by activating a wide variety of protective mechanisms designed to prevent pathogen replication and spreading [5]. The defense mechanisms including production of reactive oxygen species (ROS) [6]; alterations in the cell wall constitution; accumulation of secondary metabolites [7-10]; activation and/or synthesis of defense peptides and proteins [11].

The involvement of phenols as secondary plant metabolites in plant disease resistance is based on to large extent on their cytotoxicty. This is associated with their oxidation products [12]. Phenolics present in healthy, uninfected plant tissues, as preformed antimicrobial compounds, that inhibit the growth of fungi may include simple phenols, phenolic acids, flavonols, some isoflavones and alkaloids $[13,14]$. Phenolics seem to inhibit disease development through different mechanisms involving the inhibition of extracellular fungal enzymes (cellulases, pectinases, laccase and xylanase), inhibition of fungal oxidative phosphorylation, nutrient deprivation (metal complexation, protein insolubilisation), the inhibition of both spore germination and mycelial growth of different pathogenic fungi and antioxidant activity in plant tissues [15-17].

Corresponding Author: Heba I. Mohamed, Lecturer of Plant Physiology, Biological and Geological Sciences, Faculty of Education, Ain shams university, El Makres St. Roxy, Cairo, Egypt.

(ARE) Post code: 1575, Mob: +0123754036, E-mail: hebaibrahim79@yahoo.com. 
The production of reactive oxygen species (ROS) is one of the earliest cellular responses following successful pathogen recognition. The generation of ROS such as the superoxide anion $\left(\mathrm{O}^{2 \cdot-}\right)$ and hydrogen peroxide $\left(\mathrm{H}_{2} \mathrm{O}_{2}\right)$ are a common event associated with normal plant biochemical processes [18] and also causes oxidative damage through actions such as lipid peroxidation with membrane destruction, protein inactivation and DNA mutation [19]. $\mathrm{H}_{2} \mathrm{O}_{2}$ generation have direct antimicrobial activity inhibiting germination of spores of many fungal pathogens and participation in the formation of phenoxylradicals during phenol-polymerization within the plant cell wall [20].

Various antioxidant enzymes such as peroxidase (POX), superoxide dismutase (SOD), catalase (CAT) and ascorbate peroxidase (APX) participate in ROS metabolism during the pathogen attack. POX may be some of the elements of the defense systems that are stimulated in plants in response to pathogen infection like Fusarium oxysporum [21].

Peroxidases (POXs, EC 1.11.1.7; donor: $\mathrm{H}_{2} \mathrm{O}_{2}$ oxidoreductase) are oxido-reductive enzymes that participate in the wall-building processes such as oxidation of phenols, suberization and lignifications of host plant cells during the defense reaction against pathogenic agents [22]. One of the important physiological roles of POXs is the synthesis of cell-wall polymers (lignin and suberin), which constitute physical barriers for both biotic and abiotic stresses [23, 24], which might confer the plant with high rigidity. In sorghum, POXs are involved in resistance to fungal infection [25]. Enhanced POX activity has been correlated with resistance in rice [26, 27], wheat [28], barley [29] and sugarcane [30] following the inoculation with phytopathogens.

Polyphenol oxidases (PPOs, EC1.14.18.1; monophenol, 3,4-L-dihydroxyphenylalanine: oxygen oxidoreductase) play an important role in plant defense via the oxidation of endogenous phenolic compounds into o-quinones, which are toxic to invading pathogens and pests [13]. PPO activity in plants increases upon fungal infections [25].

Accumulation of proline occurs in response to many abiotic stresses including drought, salinity and frost as well as biotic stresses such as pathogen infection $[31,32]$

The aim of the present study was to determine the changes in secondary metabolites of flax leaves and stems in response to powdery mildew infection.

\section{MATERIALS AND METHODS}

Plant Material: Flax cvs., i.e Wildon (P2) as tolerant parent and Cortland (P3) as sensitive ones were crossed, $F_{1}$ was self pollinated to generate $F_{2}$ seeds. $F_{2}$ individuals were subjected to PM infection; disease incidence and severity were rated as follows:

Disease Incidence; plants showing even a single spot of infection.

Disease severity; Percentage of number of infected leaves out of the total number of leaves on the plant. Individual plants showing disease severity $0-10 \%$ were selected as resistant, while plants showing $90-100 \%$ disease severity were selected as susceptible. Flowers of selected plants were bagged and left for self pollination; seeds of each individual selected plant were harvested separately and planted at the next generation. The same selection criteria were used for five successive seasons; as a result, several lines with constant response to infection were generated (either resistant or sensitive). $\mathrm{F}_{7}$ lines were used for this study. Twelve resistant lines and five susceptible ones along with their respective tolerant and susceptible parent were used. The selected lines were grown in a pot trial in three replicates and left out doors during the winter seasons 2008-2009. Natural infection was occurred, samples were obtained at vegetative stage (65 days after germination) and the following parameters were tested.

Flax lines were considered resistant when showing disease severity $0-10 \%$, while lines showing $90-100 \%$ disease severity were selected as highly susceptible.

Determination of Soluble Protein: Two grams of fresh sample were homogenized in cold phosphate buffer $(0.05 \mathrm{M}$ at $\mathrm{pH} 6.5)$. The homogenate was centrifuged at $1000 \mathrm{rpm}$ for 10 minutes. The filtrate was completed to a known volume. The total protein content of plant tissue was estimated according to the method of [33] and was measured at $595 \mathrm{~nm}$ using spectrophotometer.

Determination of Antioxidant Enzymes: Peroxidase (EC 1.11.1.7) and Polyphenol oxidase (EC 1.14.18.1) was assayed following the method described by [34]. The colour intensity was read at $430 \mathrm{~nm}$ and the enzyme activity was expressed as the change in the optical density/gram fresh weight/hour.

Catalase (EC 1.11.1.6) was assayed following the method of [34]. The colour intensity was read at $240 \mathrm{~nm}$. Catalase activity was expressed as ìmole $\mathrm{H}_{2} \mathrm{O}_{2}$ destroyed /gram fresh weight/hour. 
Determination of Total Proline: The total proline of fresh leaves was estimated according to [35]. The absorbance was determined at $520 \mathrm{~nm}$. The concentration of proline was determined as ug $\mathrm{g}^{-1}$ fresh leaves.

Determination of Total Phenols: Levels of soluble phenols in stems of flax lines were determined in accordance with [36]. The absorbance of the developed blue colour was read at $725 \mathrm{~nm}$. Tannic acid was used as standard and the amount of soluble phenols was expressed as mg tannic acid $\mathrm{g}^{+}$dry weight.

Determination of Alkaloids: Alkaloids were measured according to the method described by [37]. The weight of alkaloids was then expressed as $\mathrm{mg}^{-1}$ dry weight.

Statistical Analysis: All data were subjected to statistical analysis, means were compared by Duncan's multiple range test using Mstat $\mathrm{C}$ commuter package.

\section{RESULTS AND DISCUSSION}

Changes in Secondary Metabolites: Table (1) showed that the total alkaloids and phenols content in flax stems increased significantly in resistant lines as compared with resistant parent. Also, they decreased significantly in susceptible lines and susceptible parent when both comparing with resistant parent. Plants have the ability to synthesize a large number of aromatic substances, most of which are phenols or their oxygen-substituted derivatives [38]. Most are secondary metabolites, which may be in the form of simple phenols and phenolic acids, flavonoids and alkaloids. These substances serve as plant defense mechanisms against predation by insects, herbivores and microorganisms [39]. Different studies showed that there are often large increases in phenolic synthesis in plants after attack by plant pathogens $[40,41]$.

In resistant plants, phenolic based defense responses are characterized by the early and rapid accumulation of phenolics at the infection site resulting in the effective isolation of the pathogen [42-44]. Results of many previous studies suggested that esterification of phenols to cell wall materials and the accumulation and deposition of phenols in and on cell walls are usually considered as an increase in resistance to fungal hydrolytic enzymes as well as a physical barrier against fungal penetration [45].

Changes in Proline and Total Soluble Proteincontent: Table (1) showed that proline markedly increased in resistant and susceptible lines as compared with their respective parents. This increase was much pronounced in tolerant than resistant lines. These results are in agreement with the records [46] that proline concentration peaked in frost- and snow mould resistant genotype 561 and were 25 times higher in comparison with the control

Table 1: Effect of powdery mildew on secondary metabolites, total soluble protein and proline contents in different lines of flax stems

\begin{tabular}{|c|c|c|c|c|c|}
\hline Lines & Disease reaction & Total phenol (mg tannic acid/g) & Alkaloids (mg/g) & Total soluble protein $(\mathrm{mg} / \mathrm{ml})$ & Proline( $\mu \mathrm{g} / \mathrm{g}$ fresh weight) \\
\hline 1 & R Parent & $3.20^{\mathrm{d}-\mathrm{h}}$ & $14.67^{\mathrm{efg}}$ & $39.11^{\mathrm{d}-\mathrm{g}}$ & $1.94^{\text {fgh }}$ \\
\hline 2 & $\mathrm{R}$ & $3.50^{\mathrm{d}-\mathrm{g}}$ & $29.67^{\mathrm{a}}$ & $42.33^{\mathrm{bcd}}$ & $2.70^{\mathrm{e}}$ \\
\hline 3 & $\mathrm{R}$ & $3.36^{\mathrm{d}-\mathrm{h}}$ & $21.00^{\mathrm{bcd}}$ & $45.11^{\mathrm{b}}$ & $5.67^{\mathrm{b}}$ \\
\hline 4 & $\mathrm{R}$ & $5.41^{\mathrm{ab}}$ & $21.67^{b c d}$ & $44.33^{b}$ & $6.46^{\mathrm{a}}$ \\
\hline 5 & $\mathrm{R}$ & $4.12^{\mathrm{cde}}$ & $18.00^{\text {cde }}$ & $50.08^{a}$ & $3.54^{\mathrm{d}}$ \\
\hline 6 & $\mathrm{R}$ & $4.93^{\mathrm{abc}}$ & $17.33^{\mathrm{def}}$ & $41.11^{\mathrm{b}-\mathrm{e}}$ & $5.32^{\mathrm{bc}}$ \\
\hline 7 & $\mathrm{R}$ & $4.32^{\mathrm{bcd}}$ & $20.33^{b c d}$ & $44.04^{b c}$ & $2.21^{\mathrm{efg}}$ \\
\hline 8 & $\mathrm{R}$ & $3.53^{\mathrm{d}-\mathrm{g}}$ & $22.33^{b}$ & $44.14^{b}$ & $2.19^{\mathrm{fg}}$ \\
\hline 9 & $\mathrm{R}$ & $5.53^{\mathrm{f}-\mathrm{i}}$ & $22.33^{\mathrm{b}}$ & $42.11^{\mathrm{bcd}}$ & 2.44 ef \\
\hline 10 & $\mathrm{R}$ & $6.03^{\mathrm{a}}$ & $18.33^{\text {cde }}$ & $39.88^{\mathrm{c}-\mathrm{f}}$ & $2.20^{\mathrm{efg}}$ \\
\hline 11 & $\mathrm{R}$ & $4.34^{\mathrm{bcd}}$ & $17.00^{\text {fgh }}$ & $44.62^{\text {в }}$ & $3.54^{\mathrm{d}}$ \\
\hline 12 & $\mathrm{R}$ & $3.66^{\mathrm{def}}$ & $19.67^{b c d}$ & $42.27^{\mathrm{bcd}}$ & $4.85^{c}$ \\
\hline 13 & H.S Parent & $2.88^{\mathrm{e}-\mathrm{i}}$ & $13.67^{\mathrm{fgh}}$ & $21.10^{\mathrm{i}}$ & $1.47^{\mathrm{h}}$ \\
\hline 14 & $\mathrm{~S}$ & $1.81^{\mathrm{ij}}$ & $11.00^{\text {ghi }}$ & $35.40^{\mathrm{gh}}$ & $1.72^{\mathrm{gh}}$ \\
\hline 15 & $\mathrm{~S}$ & $1.75^{\text {hij }}$ & $13.67^{\text {fgh }}$ & $35.82^{\text {fgh }}$ & $1.46^{\mathrm{h}}$ \\
\hline 16 & $\mathrm{~S}$ & $2.37^{\mathrm{g}-\mathrm{j}}$ & $9.67^{i}$ & $36.78^{f g}$ & $2.28^{\text {ef }}$ \\
\hline 17 & $\mathrm{~S}$ & $1.41^{\mathrm{j}}$ & $10.00^{\mathrm{hi}}$ & 37.72 efg & $2.26^{\text {ef }}$ \\
\hline 18 & $\mathrm{~S}$ & $2.59^{f-j}$ & $10.00^{\mathrm{hi}}$ & $32.01^{\mathrm{h}}$ & $2.15^{\mathrm{fg}}$ \\
\hline \multicolumn{2}{|c|}{ L. S.D at $5 \%$} & 1.26 & 3.76 & 4.2030 & 0.5087 \\
\hline
\end{tabular}

Different letters indicate a significant difference according to Duncan's multiple range test.

$\mathrm{R}$ means resistant

S means susceptible 
World J. Agric. Sci., 7 (1): 78-85, 2011

Table 2: Effect of powdery mildew on antioxidant enzymes in leaves of different flax lines

\begin{tabular}{|c|c|c|c|c|}
\hline Lines & Disease reaction & Polypheny oxidase activity/g fresh weight/h) & Peroxidase (activity/g fresh weight $/ \mathrm{h}$ ) & Catalase $\left(\mu \mathrm{M} \mathrm{H}_{2} \mathrm{O}_{2} / \mathrm{g}\right.$ fresh weight $\left./ \mathrm{h}\right)$ \\
\hline 1 & R Parent & $15.26^{\mathrm{d}}$ & $9.14^{\mathrm{fg}}$ & $26.20^{\mathrm{i}}$ \\
\hline 2 & $\mathrm{R}$ & $18.11^{\mathrm{g}}$ & $10.16^{\mathrm{fg}}$ & $27.56^{\mathrm{g}}$ \\
\hline 3 & $\mathrm{R}$ & $19.01^{\mathrm{hij}}$ & $22.08^{\text {bcd }}$ & $28.55^{\text {def }}$ \\
\hline 4 & $\mathrm{R}$ & $15.78^{\mathrm{ij}}$ & $25.24^{\mathrm{a}}$ & $28.68^{\text {cdef }}$ \\
\hline 5 & $\mathrm{R}$ & $18.03^{\mathrm{f}}$ & $21.44^{\mathrm{cd}}$ & $27.48^{\mathrm{g}}$ \\
\hline 6 & $\mathrm{R}$ & $18.70^{\mathrm{g}}$ & $20.16^{\mathrm{d}}$ & $28.88^{\text {cde }}$ \\
\hline 7 & $\mathrm{R}$ & $19.04^{\mathrm{g}}$ & $11.63^{\mathrm{fg}}$ & $30.96^{\mathrm{a}}$ \\
\hline 8 & $\mathrm{R}$ & $17.05^{\mathrm{e}}$ & $23.00 \mathrm{abc}$ & $29.56^{\mathrm{b}}$ \\
\hline 9 & $\mathrm{R}$ & $19.76^{\mathrm{k}}$ & $24.56^{\mathrm{ab}}$ & $27.28^{\mathrm{g}}$ \\
\hline 10 & $\mathrm{R}$ & $16.63^{\mathrm{hi}}$ & $20.84^{\mathrm{cd}}$ & $27.36^{\mathrm{g}}$ \\
\hline 11 & $\mathrm{R}$ & $18.54 \mathrm{j}$ & $9.82^{\mathrm{fg}}$ & $27.39^{g}$ \\
\hline 12 & $\mathrm{R}$ & $21.04^{b}$ & $15.66^{\mathrm{e}}$ & 29.03 bcd \\
\hline 13 & H.S Parent & $12.47^{\mathrm{c}}$ & $4.61^{\mathrm{i}}$ & $25.48^{j}$ \\
\hline 14 & S & $12.91^{\mathrm{j}}$ & $4.62^{\mathrm{i}}$ & $26.71^{\text {hi }}$ \\
\hline 15 & S & $12.03^{\mathrm{a}}$ & $5.86^{\mathrm{hi}}$ & $27.08^{\text {gh }}$ \\
\hline 16 & S & $13.94^{\mathrm{c}}$ & $6.05^{\text {hi }}$ & $28.19^{f}$ \\
\hline 17 & S & $14.70^{\mathrm{g}}$ & $8.03^{\text {gh }}$ & $28.44^{\text {ef }}$ \\
\hline 18 & $\mathrm{~S}$ & $13.34^{\mathrm{hi}}$ & $6.51^{\mathrm{hi}}$ & $29.23^{\mathrm{bc}}$ \\
\hline \multicolumn{2}{|c|}{ L. S.D at $5 \%$} & 0.091 & 2.16 & 0.550 \\
\hline
\end{tabular}

Different letters indicate a significant difference according to Duncan's multiple range test.

$\mathrm{R}$ means resistant

S means susceptible

plants and 5 times higher than that of the susceptible genotype 621. Also, proline index the indicator of predisposition in tomato plants to Phytophtora nicotianae infection as influenced by abiotic stresses [47]. In addition proline concentration in foliar tissues of pepper plants inoculated with Verticillium dahliae increased significantly between days 21 and 28 after inoculation, while they did not change in the leaves of control plants [48]. In cotton, higher proline levels were detected in leaves from inoculated plants with Verticillium than in those from controls [49].

The amino acid proline may act as a potent scavenger of ROS and this property of proline might prevent the induction of programmed cell death by ROS [50]. Proline may also function as a protein compatible hydrotrope [51] and as a hydroxyl radical scavenger [52]. In any case the higher proline accumulation in diseased tissue might be related to pathological disorder [53].

Data presented in Table (1) also showed that, total soluble protein content in flax leaves increased significantly in resistant lines as compared with resistant parent. In this regard, an opposite feature was observed in susceptible lines comparing with resistant parent. Plant pathogens such as bacteria and fungi elicit the synthesis of host proteins which help in restricting the multiplication and spread of pathogens in the healthy tissue [54]. Also, [55] showed that the presence of pathogenesis-related (PR) proteins, such as chitinase, $\beta$-1,3-glucanase or thaumatin in the tissue infected by pathogens positively correlates with the plant resistance to micro-organisms. In addition to, in cucumber, the resistance was associated with the induction of pathogenesis-related proteins (i.e. chitinases) [56] and POX [57] in extracellular spaces of the host tissues following treatment.

Changes in Antioxidant Enzymes: It is well known that organisms protect themselves against oxidatives stress by the synthesis of various antioxidant enzymes. Results in Table (2) showed that infection with powdery mildew significantly increased peroxidase, polyphenyl oxidase and catalase activities in leaves of flax lines as compared with resistant and susceptible parents.

POX activity was noted to increase significantly in both resistant and susceptible lines as compared with their parent. These results are in agreement with other studies [58], which reported that increase in peroxidase activity enhance lignifications in response to chocolate spot infection which may restrict the fungal penetration. These findings indicate to a positive relationship between resistance and peroxidase activity. Peroxidase also produces free radicals and hydrogen peroxide which are toxic to many microorganisms [59]. Another supportive suggestion was brought by [13] who found that, a significant increase in POX specific activity in both resistant (Wang-shuibai) and susceptible (Falat) wheat 
cultivars following the inoculation with $F$. graminearum conidia. Also, an increase in peroxidase activity is considered as a preliminary indicator for resistance of broad beans to chocolate spot disease [60]. These compounds act as barriers against pathogen invasion.

POXs are usually associated with induced resistance [61] and they are also implicated in several plant defense mechanisms such as lignin synthesis, oxidative cross linking of different plant cell wall components or generation of reactive oxygen species [62].

Data also showed that PPO markedly increased in resistant and susceptible lines as compared with resistant and susceptible parents. While in susceptible lines, PPO significantly decreased as compared to resistant parent. These results are in agreement with findings that PPO may confer resistance to some fungal species such as $R$. sorghicola [25]. PPO specific activity significantly increased in wheat heads of resistant and susceptible cultivars following the inoculation with $F$. graminearum conidia [13]. Similar results have been obtained in plant-pathogenic fungal interactions such as cabbage $F$. oxysporum, onion/Botrytis, sunflower/Sclerotinia sclerotiorum, soybean/Phytophthora megasperma and bean /Rhizoctonia [63]. In addition, pretreatment of Chick pea with rhizobium increased significantly the levels of peroxidase and polyphenyl oxidase and total phenolics was recorded [64]. These increases were the most effective reducing Fusarium wilt development. POX and PPO are important in the defense mechanism against pathogens, through its role in the oxidation of phenolic compounds to quinines, causing increasing in antimicrobial activity. Therefore, its may be directly involved in stopping pathogen development [65, 66]; accelerating the cellular death of cells close to the infection site, preventing the advance of infection and/or by generating a toxic environment which will inhibit the growth of the pathogen inside the cells [67].

Catalase activity was increased markedly in flax leaves of resistant and susceptible lines (Table 2). This increase was much pronounced in tolerant lines than resistant lines. This increase in catalase activity may provide its protection from oxidative damage by rapid removal of $\mathrm{H}_{2} \mathrm{O}_{2}$. These results were in agreement with those recorded that, the activity of antioxidant enzymes in leaves under Fusarium oxysporum infection increased and might be affective in scavenging mechanism to remove $\mathrm{H}_{2} \mathrm{O}_{2}$ and $\mathrm{O}_{2}{ }^{-}$produced in leaves [68]. Also, in banana plants, it was reported that, levels of $\mathrm{H}_{2} \mathrm{O}_{2}$ and other enzyme activities were increased to the levels of tolerance or susceptibility to Fusarium wilt disease [69].
The obtained results in the present study lead to conclude that the total alkaloids, phenols and total soluble protein content in flax stems significantly increased in resistant lines but decreased in susceptible ones and susceptible parent when the both compared with resistant parent. The activity of peroxidase, polyphenyl oxidase, catalase enzymes as well as proline content were significantly increased in powdery mildew infected leaves of flax lines as compared with either resistant or susceptible parents.

\section{ACKNOWLEDGMENT}

This work was supported in part by the project entitled with (Isolation of powdery mildew resistance gene(s) in flax), funded by the external actions of EU community.

\section{REFERENCES}

1. Aly, A.A., A.Z.A. Ashour, E.A.F. El-Kady and M.A. Mostafa, 1994. Effectiveness of fungicides or control of powdery mildew in flax and effect of the disease on yield and yield components. Agri. Sci. Mansoura University, 19: 4383-4393.

2. Ashry, N.A., M.T.M. Mansour, M.E.M. Hasan and A.A. Ali, 2002. Use of RAPD analysis as molecular markers for powdery mildew resistance in flax. Egyptian J. Genetics and Cytol., 31(2): 279-285.

3. Ashry, N.A., M. Masour and H.M. El-Demerdash, 2005. Use of gamma rays to induced powdery mildew resistance mutants in flax. Egyptian J. Plant Breeding, 9(2): 303-315.

4. Mansour, M.T.M., A.A. Aly, S.M.E Zayed and M.A. Mostafa, 1999. Effectiveness of seed treatments and foliar fungicides for control of powdery mildew of flax cultivars. Agri. Sci. Mansoura University, 24: 5497-5608.

5. Malolepsza, U. and S. Rózalaska, 2005. Nitric oxide and hydrogen peroxide in tomato resistance. Nitric oxide modulates hydrogen peroxide level in O.hydroxyethylorutin-induced resistance to Botrytis cinerea in tomato. Plant Physiol. Biochemistry, 43: 623-635.

6. De Gara, L., M. De Pinto and F. Tommasi, 2003. The antioxidant systems via reactive oxygen species during plant-pathogen interaction. Plant Physiol. and Biochemistry, 41: 863-870.

7. Benner, J.P., 1993. Pesticidal compounds from higher plants. Pesticide Sci., 39: 95-102. 
8. Bennett, R.N. and R.M. Wallsgrove, 1994. Secondary metabolites in plant defense mechanisms. New Phytologist, 127: 617-633.

9. Heath, M., 2000. Hypersensitive response related death. Plant Molecular Biology, 44: 321-334.

10. Agrios, G.N., 2005. Plant Pathology. 5 Edition. Academic Press, San Diego, USA.

11. Castro, M.S. and W. Fontes, 2005. Plant defense and antimicrobial peptides. Protein and Peptide Letters, 12: 11-16.

12. Averyanov, A.A. and V.P. Lapikova, 1994. Partcipation of active forms of oxygen in the mechanism of ferulic acid toxicity. Biology Bulletin (Izvestiya Akademii Nauk SSSR, Seriya Biologicheskaya), 4: 352-357.

13. Mohammadi, M. and H. Kazemi, 2002. Changes in peroxidase and polyphenol oxidase activities in susceptible and resistant wheat heads inoculated with Fusarium graminearum and induced resistance. Plant Sci., 162: 491-498.

14. Chérif, M., A. Arfaoui and A. Rhaiem, 2007. Phenolic Compounds and their Role in Bio-control and Resistance of Chickpea to Fungal Pathogenic Attacks. Tunisian J. Plant Protection, 2(1): 7-21.

15. Jersh, S., C. Scherer, G. Huth and E. Schlosser, 1989. Proanthocyanidins as basis for quiescence of Botrytis ciberea in immature strawberry. J. Plant Patholol., 22: 67-70.

16. Mandeel, Q. and R. Baker, 1991. Mechanisms involved in biological control of Fusarium wilt of cucumber with strains of non-pathogenic Fusarium oxysporum. Phytopathol., 81: 462-469.

17. Scalbert, A., 1991. Antimicrobial properties of tannins. Phytochemistry, 30: 3875-3883.

18. Zhao, J., L.C. Daves and R. Verpoorte, 2005. Elicitor signal transduction leading to production of plant secondary metabolites. Biotechnology Advances, 23: 283-333.

19. Torres, M.A., D.G. Jonathan and J.L. Dangl, 2006. Reactive oxygen species signaling in response to pathogen. Plant Physiol., 141: 373-378.

20. Lamb, C. and R.A. Dixon, 1997. The oxidative burst in plant disease resistance. Annual Review Plant Physiology Plant Molecular Biol., 48: 251-257.

21. Morkunas, I. and J. Gemerek, 2007. The possible involvement of peroxidase in defense of yellow lupine embryo axes against Fusarium oxysporum. J. Plant Physiol., 164: 497-506.
22. Chittoor, J.M. and F.F. Leach, 1999. Induction of peroxidase during defense against pathogens, in: S.K. Datta, S. Muthukrishnan (Eds.), Pathogenesis: Related Proteins in Plants, CRC Press, Boca Raton, FL, pp: 291.

23. Cosgrove, D.J., 1997. Assembly and enlargement of the primary cell wall in plants. Annual Review Cell and Developmental Biol., 13: 171-201.

24. Quiroga, M., C. Guerrero, M.A. Botella, A. Barcelo', I. Amaya, M.I. Medina, F.J. Alfonso, Milrad S. De Forchetti, H. Tigier and V. Valpuesta, 2000. A tomato peroxidase involved in the synthesis of lignin and suberin. Plant Physiol., 122: 1119-1128.

25. Luthra, Y.P., S.K. Ghandi, U.N. Joshi and S.K. Arora, 1988. Total phenols and their oxidative enzymes in sorghum leaves resistant and susceptible to Ramulispora sorghicola Harris. Acta Phytopathologica et Entomologica Hungarica, 23: 393-400.

26. Reimers, P.J., A. Guo and J.E. Leach, 1992. Increased activity of a cationic peroxidase associated with an incompatible interaction between Xanthomonas oryzae pv. oryzae and rice (Oryza sativa). Plant Physiol., 99: 1044-1050.

27. Young, S.A., A. Guo, J.A. Guikema, F.F. White and J.A. Leach, 1995. Rice cationic peroxidase accumulates in xylem vessels during incompatible interactions with Xanthomonas oryzae pv. Oryzae. Plant Physiol., 107: 1333-1341.

28. Flott, B.E., B.M. Moerschbacher and H. Reisener, 1989. Peroxidase isoenzyme patterns of resistant and susceptible wheat leaves following stem rust infection. New Phytologist, 111: 413-421.

29. Kerby, K. and S. Somerville, 1989. Enhancement of specific intercellular peroxidases following inoculation of barley with Erysiphe graminis f. sp. hordei. Physiological and Molecular Plant Pathol., 35: 323-337.

30. McGhie, T.K., N.P. Masel, D. Maclean, B.J. Croft and G.R. Smith, 1997. Biochemical responses of suspension-cultured sugarcane cells to an elicitor derived from the root pathogen Pachymetra chaunorhiza, Australian J. Plant Physiol., 24: 143-149.

31. Hare, P.D. and W.A. Cress, 1997. Metabolic implications of stress-induced proline accumulation in plants. Plant Growth Regululation, 21: 79-102. 
32. Slama, I., D. Messedi, T. Ghnaya, A. Savoure and Abdelly Ch, 2006. Effects of water deficit on growth and proline metabolism in Sesuvium portulacastrum. Environmental and Experimental Bot., 56: 231-238.

33. Bradford, M.M., 1976. A rapid and sensitive method for the quantitation of microgram quantities of protein utilizing the principle of protein-dye binding. Analytical Biochemistry, 72: 248-254.

34. Kar, M. and D. Mishra, 1976. Catalase, peroxidase and polyphenol oxidase activity during leaf senescence. Plant Phsiolol., 57: 315.

35. Bates, L.S., R.P. Waldren and L.D. Teare, 1973. Rapid determination of free proline for water stress studies. Plant and Soil., 39: 205-207.

36. Dihazi, A.D., F. JaitI, J. Zouine, M.E. Hassni and I.E. Hardami, 2003. Effect of salicylic acid on phenolic compounds related to data palm resistance to Fusarium oxysporum sp. Albedimis. Phytopathologia Mediterrranea, 423: 9-16.

37. Harbone, J.B., 1973. Phytochemical methods, a guide to modern techniques of plant analysis. Chapman and Hall. London, pp: 185-186.

38. Cowan, 1999. Plant products as antimicrobial agents. Clinical Microbiol., 12: 564-582.

39. Beckman, C.H., 2000. Phenolic-storing cells: keys to programmed cell death and periderm formation in wilt disease resistance and in general defense responses in plants. Physiology Molecular Plant Patholology 57: 101-110.

40. Matern, U., B. Grimmig and R.E. Kneusel, 1995. Plant cell wall reinforcement in the disease-resistance response: molecular composition and regulation. Canadian J. Botany, 73: 511-517.

41. De Ascensao, A.F. and I.A. Dubrey, 2003. Soluble and wall-bound phenolic polymers in Musa acuminata roots exposed to elicitors from Fusarium oxysporum.sp. cubens. Phytochemistry, 63: 679-686.

42. Chérif, M., N. Benhamou and R.R. Bélangeret, 1991. Ultrastructural and cytochemical studies of fungal development and host reactions in cucumber plants infected by Pythium ultimum. Physiological and Molecular Plant Pathol., 39: 353-375.

43. Chérif, M., N. Benhamou, J.G. Menzies and R.R. Bélanger, 1992. Silicon-induced cellular defense reactions in cucumber plants attacked with Pythium ultimum Physiological and Molecular Plant Pathol., 41: 411-425.
44. Fernandez, M.R. and M.C. Heath, 1998. Interaction of the non host French been plant (Phaseolus vulgaris) with parasitic and saprophytic fungi. III Cytologically detectable responses. Canadian J. Bot. 67: 676-686.

45. Stadnik, M.J. and H. Buchenauer, 2000. Inhibition of phenylalanine ammonia-lyase suppresses the resistance induced by benzothiadiazole in wheat to Blumeria graminis F.SP. tritici. Physiological and Molecular Plant Pathol., 57: 25-34.

46. Ewa, P., P. Agnieszka, J. Franciszek and Z. Zbigniew, 2009. ABA level, proline and phenolic concentration and PAL activity induced during cold acclimation in androgenic Festulolium forms with contrasting resistance to frost and pink snow mould (Microdochium nivale). Physiological and Molecular Plant Pathol., 73: 126-132.

47. Grote, D., R. Schmidt and Claussen, 2006. Water uptake and proline index as indicators of predisposition in tomato plants to Phytophtora nicotianae infection as influenced by abiotic stresses. Physiological and Molecular Plant Pathol., 69: 121-130.

48. Goicoechea, N., J. Aguirreolea, S. Cenoz and. J.M. Garcia-Mina, 2000. Verticillium dahliae modifies the concentrations of proline, soluble sugars, starch, soluble protein and abscisic acid in pepper plants. European J. Plant Patholol., 106: 19-25.

49. Tzeng, D.D., R.J. Wakeman and J.E. DeVay, 1985. Relationships among Verticilliumwilt development, leafwater potential, phenology and lint yield in cotton. Physiologial Plant Pathol., 26: 73-81.

50. Chen, C. and M.B. Dickman, 2005. Proline suppresses apoptosis in the fungal pathogen Colletotrichum trifolli. Proceedings of the National Academy of Sci. USA, 102: 3459-3464.

51. Srinivas, V. and D. Balasubraman, 1995. proline is a protein compatible hydrotrope. Langmuir, 11: 2830-2833.

52. Smimoff, N. and Q.J. Cumbes, 1989. Hydroxyl radical scavenging activity of compatible solutes. Phtochemistry, 28: 1057-1060.

53. Chatterjee, A. and S.K. Ghosh, 2008. Alterations in biochemical components in mesta plants infected with yellow vein mosaic disease. Brazilian J. Plant Physiol., 20(4): 267-275.

54. Datta, K., S. Muthukrishnan and S.K. Datta, 1999. Expression and function of PR-proteins genes in transgenic plants. In:Datta, S.K., Pathogenesisrelated proteins in plants. 261-291. CRC Press, Boca Raton. 
55. gnieszka, P. and Z. Iwona, 2003. Cold-induced plant resistance to necrotrophic pathogens and antioxidant enzyme activities and cell membrane permeability. Plant Sci., 164: 1019-/1028.

56. Metraux, L., W. Burkhart, M. Moyer, S. Dincher, W. Middlesteadt, S. Williams, G. Payne, M. Carnes and J. Ryals, 1989. Isolation of a complementary DNA encoding a chitinase with structural homology to a bifunctional lysozyme/chitinase. Proceedings of the National Academy of Sci. USA, 86: 896-900.

57. Cloud, A.M.E. and B.J. Deverall, 1987. Induction and expression of systemic resistance to the anthracnose disease in bean. Plant Pathol., 36: 551-557.

58. Tarred, A.M., Y.Y. El-Hyatemy and S.A. Omar, 1993. Wyerone derivatives and activities of peroxidase and polyphenol oxidase in faba bean leaves as induced by chocolate spot disease. Plant Sci., 89: 161-165.

59. Pena, M. and J.A. Kuc, 1992. Peroxidase-generated hydrogen peroxidase as a source of antifungal activity in vitro and on tobacco leaf disks. Phytopathol., 82: 696-699.

60. Nawar, H.F. and J.D. Kuti, 2003. Wyerone acid phytoalexin synthesis and peroxidase activity as markers for resistance of broad beans to chocolate spot disease. J. Phytopathol., 151: 564-570.

61. Rasmussen, J.B., J.A. Smith, S. Williams, W. Burkhatr and E. Ward, 1995. cDNA cloning and systemic expression of acidic peroxidases associated with systemic acquired resistance to disease in cucumber. Physiological and Molecular Plant Pathol., 46: 398-400.

62. Mehdy, M.C., 1994. Active oxygen species in plant defense against pathogens. Plant Physiol., 105: 476-472.
63. Goodman, R.N., Z. Kiraly and K.R. Wood, 1986. The Biochemistry and Physiology of Plant Disease, University of Missouri Press, USA, pp: 433.

64. Arfaoui A., B. Sifi, I. El Hassni, I. El Hadrami, A. Boudabous and M. Chérif, 2005. Biochemical analysis of chickpea protection against Fusarium wilt afforded by two Rhizobium isolates. Plant Patholology J., 4: 35-42.

65. Shimzu, N., N. Hosogi, G.S., Hyon, S. Jiang, K. Inoue and P. Park, 2006. Reactive oxygen species (ROS) generation and ROS induced lipid peroxidation are associated with plant membrane modifications in host cells in response to AK-toxin from Alternaria alternate Japanese pear pathotype. J. General Plant Pathol., 72: 6-15.

66. Melo, G.A., M.M. Shimizu and P. Mazzafera, 2006. Polyphenoloxidase activity in coffee leaves and its role in resistance against the coffee leaf miner and coffee leaf rust. Photochemistry, 67: 277-285.

67. Bi, J.L. and G.W. Felton, 1995. Foliar oxidative stress and insect herbivory: primary compounds, secondary metabolites and reactive oxygen species as components of induced resistance. J Chemical Ecol., 21: 1511-1530.

68. El- Khallal, S.M., 2007. Induction and modulation of resistance in tomato plants against Fusarium wilt disease by bioagent fungi (arbuscular mycorrhiza) and/or hormonal elicitors (jasmonic acid and salicylic acid): 2-changes in the antioxidant enzymes, phenolic compounds and pathogen related- proteins. Australian J. Basic and Applied Sci., 1(4): 717-732.

69. Subramaniam, S., M. Moziah, M. Sariah M.P. Puad and R. Xavier, 2006. Bioassay method for testing Fusarium wilt disease tolerance in transgenic banana. Scientia Horticulturae, 108: 378-389. 